\title{
StATE-BASED BUSINESS LICENSING IN Australia: THE CONSTITUTION, ECONOMICS AND INTERNATIONAL Perspectives
}

\section{ANTHONY GRAY*}

This article considers the current controversial question of the continuing existence of state licensing systems in relation to businesses and occupations. While there may be good reasons for such regimes, differing requirements in different jurisdictions can have the effect of making it more difficult for families and individuals to conduct business in particular jurisdictions, and can inhibit them from moving between jurisdictions. These restrictions could, in the view of economists, lead to inefficient use of human resources. The article considers the extent to which section 92 of the Constitution might be invoked to challenge such regulations, bearing in mind past case law on the section and the recent Betfair decision.

\section{INTRODUCTION}

The extent of regulation over the right to work in particular fields is of ongoing concern in Australia. Regulations prescribing the requirements to work in particular fields are currently largely state-based. While there may be good reasons for this, different regimes create various anomalies. In this paper, I outline the practical difficulties caused by the present patchwork quilt of different regimes regulating the right to work in particular fields, before considering the extent to which Australia's constitutional arrangements might cut red tape in this regard. In so doing, I shall consider a recent High Court decision in some detail, and an account will be given of how this issue has been dealt with in other parts of the world. Of course, as with many other issues, this issue is not one confronting only Australia. It confronts other federal systems as well. 


\section{The Problem}

The problem of multiple business licensing schemes and of the recognition of qualifications obtained in other jurisdictions has at least been recognised by government, with the issue of national recognition of trade qualifications being on the Council of Australian Governments' (COAG) list of Top 10 hotspots, or worst regulatory impediments to economic activity. ${ }^{1}$ The Business Council of Australia has counted 149 occupational licensing schemes in New South Wales, 136 in Victoria, 87 in Western Australia, 69 in the Australian Capital Territory, and 47 at the Commonwealth level. ${ }^{2}$

The current arrangements might have made sense in a past era, but are increasingly questionable today. There is clear evidence that business is increasingly being done across state lines. By the end of the 2007 financial year, more than 31700 businesses in Australia were operating in more than one jurisdiction, with 4300 operating in all nine jurisdictions. This figure has increased by 70 per cent since $2003 .^{3}$

The problems caused by multiple licensing schemes were identified by the Australian National Training Authority (ANTA), in its 2002 Report A Licence to Skill. ${ }^{4}$ ANTA had been required to develop training packages at the national level, in an effort to create an integrated national vocational education and training system. These packages would ensure that people wishing to enter particular trades had a series of defined skills and abilities. However, the Report found that these packages were not being used by all bodies responsible for industry licensing. ${ }^{5}$ Often additional factors were being used as the basis for determining competency in a particular field; sometimes the factors used were actually inconsistent with the nationally developed

\footnotetext{
* Associate Professor, School of Law, University of Southern Queensland. Thanks to the anonymous reviewer for helpful comments on an earlier draft.

1 The list comprises rail safety regulation, occupational health and safety, national trade measurement, chemicals and plastics, development assessment arrangements, building regulations, environmental assessment and approvals processes, business name, Australian Business Number and related business registration processes, personal property securities, and product safety.

2 Access Economics Pty Ltd for the Business Council of Australia, Reshaping Australia's Federation: A New Contract for Federal-State Relations; Appendix 2, 'The Costs of Federalism' (2006) 30.

${ }^{3}$ Australian Bureau of Statistics, Counts of Australian Businesses, Including Entries and Exits, June 2003 to June 2007, No 8165.0 (December 2007).

${ }^{4}$ ANTA, A Licence to Skill (2002)('Licence to Skill')

$<$ http://www.dest.gov.au/NR/rdonlyres/CE7470E2-4D4A-44B4-866A42E0C592D4D7/10799/ANTAA_Licence_to_Skill.pdf> at 20 October 2009.

${ }^{5}$ Ibid 1, 52 .
} 
standards. Requirements continued to differ across jurisdictions. ${ }^{6}$ The problem had been recognised earlier, leading to the signing in 1992 of the Australian Mutual Recognition Agreement ${ }^{7}$ involving the states and territories. The Agreement aimed to create mutual recognition of standards in states and territories regarding goods and occupations. However, the Agreement had its limitations. ${ }^{8}$ Further, while there is an ongoing COAG process to fix the identified problems with incomplete mutual recognition of qualifications, progress has been slower than first anticipated.

The idea of creating nationally-based requirements to assess workplace competency was to reduce 'barriers to the mobility of labour between jurisdictions'. ${ }^{9}$ Existing licensing regimes inhibited this. ${ }^{10}$ Some specific examples include hairdressing, where no licence is necessary in Victoria but is required in New South Wales. A Victorian hairdresser wishing to move to New South Wales would have to study at a NSW TAFE in order to gain a NSW licence. Similarly in nursing - a Northern Territory nurse working as an immunisation provider can do so without a licence in the Northern Territory; however if she/he wished to move to Victoria, she/he would need to undertake a further VET course. ${ }^{11}$ The Productivity Commission has noted the negative impact of state-based licensing systems on competition. ${ }^{12}$

\footnotetext{
${ }^{6}$ The Report refers to this as the 'rail gauge' problem, in terms of training, with analogies to the problems associated with different rail gauges in Australia.

${ }^{7}$ Council of Australian Governments

$<$ http://www.coag.gov.au/mutual_recognition/docs/mra_text.pdf $>$ at 20 October 2009.

${ }^{8}$ Licence to Skill, above n 4, 6. Specifically, it did not assist where occupations were regulated differently across jurisdictions, and did not assist where workplace requirements were mandated by legislation, but for which no licence or registration was issued.

${ }^{9}$ Ibid 9. As well as to improve consistency in the regulatory requirements of jurisdictional industry regulatory authorities, provide a sound basis to improve the mutual recognition of occupational licences between jurisdictions, and provide a strong foundation from which to develop nationally consistent regulatory regimes.

${ }^{10}$ Ibid 21.

${ }^{11}$ ANTA, Review of the Mutual Recognition Agreement - The Implications of Occupational Licensing for the Implementation of National Training Packages (Submission to the Productivity Commission from the Australian National Training Authority) (2003).

${ }^{12}$ Licensing has costs. Apart from compliance and administration costs, by restricting entry, it can reduce competition with the usual adverse outcomes for consumers. Hence, it is important that licensing is not over-used.... of the total of nearly 100 occupations licensed by the States and Territories for consumer policy reasons, more than 30 are licensed in only one or two jurisdictions... In some cases (eg hairdressing), the prima facie case for specific requirements seems very weak': Productivity Commission, Review of Australia's Consumer Policy Framework, Inquiry Report No 45, (30 April 2008) vol 1, 27.
} 
Economists would find such barriers to the free movement of labour to be inefficient. Access Economics addressed this issue in its recent paper, The Costs of Federalism: ${ }^{13}$

The States often stop the right person being in the right job - or, at least, make them go through duplicated regulatory hoops to do in one State something they have already qualified to practice [sic] in another State.

This is a big problem. Each State and Territory grants licences to practice [sic] in lots of occupations ... ${ }^{14}$

It is important to ensure that people have the necessary skills to practice [sic] particular occupations. But it is rather less clear that the licensing practices and procedures couldn't be much better co-ordinated and harmonised than they are ...

All too often, someone licensed in one State cannot readily practise in another. That is typically a triumph of bureaucracy over common sense. And while some progress has been made in individual sectors towards overcoming the impediments to a mobile workforce arising from such Statebased licensing systems, no consistent approach to resolving the problems has been devised. ${ }^{15}$

As the Business Council of Australia noted recently in relation to restrictions on the labour market and business regulation more generally:

Unnecessarily complex business regulation means that businesses continue to face needless delays, increased compliance costs, more expensive inputs, and difficulties in transferring qualified staff to the places they are most needed. These differences create barriers to growth by making businesses more expensive to run, less able to expand, less inclined to develop new products and markets, less able to compete effectively and, ultimately, less profitable. In turn, Australians face higher prices, fewer choices and more restricted employment opportunities than might otherwise be the case. And

\footnotetext{
${ }^{13}$ Above $n 2$.

14 Builders, plumbers, electricians, electrical mechanics, fitters, engineers, installing, maintaining and servicing air conditioners and refrigeration, security guards, locksmiths, bodyguards, who can own a gun, aircraft engineers, and manager of investment products are all cited.

${ }^{15}$ Ibid 30-1. Treasury Secretary Ken Henry has also noted these issues, concluding that 'we do not have a national labour market', and citing occupations such as electricians and hairdressers where, although mutual recognition is in place, problems of categorisation in the case of electricians and of work experience requirements in the case of hairdressers, inhibit the transferability of such skills: Productivity Commission, Time to Get Real on National Productivity Reform in Productive Reform in a Federal System, Roundtable Proceedings (2006) 340.
} 
the increased cost of administration for governments raises the tax burden for everyone.

When all of this is added together, it is clear that our current regulatory systems help prevent the Australian economy from operating at its potential. They represent an antiquated and anachronistic framework that stands in direct contrast to Australia's moves to reduce international regulatory barriers through the pursuit of its free trade agenda and other international economic arguments. ${ }^{16}$

Some have argued that the debate here reflects a larger debate between neoclassical economic thought, favouring decentralised economic policy and reduced national power to coordinate economic decision-making, and a Keynesian approach, favouring a macroeconomic view of the economy as an organic whole. ${ }^{17}$ Links can be seen between this debate and the jurisprudence of the United States Supreme Court. ${ }^{18}$

The Business Council argues that businesses should be able to transfer willing employees to areas where they are needed, without having to worry whether their qualifications were transferable. Businesses should be able to conduct the same business in different states, without having to re-apply for the same licences. ${ }^{19}$ The current (excess) regulation makes it difficult for Australian businesses to compete in international markets against companies from countries with less regulation. The Council points to the substantial resources that must sometimes be devoted to compliance with the rules, causing some businesses to think twice about expanding, and resulting in an opportunity cost of economic activity forgone. ${ }^{20}$

${ }^{16}$ Business Council of Australia, Towards a Seamless Economy: Modernising the Regulation of Australian Business (2008) 8.

${ }^{17}$ Steven Gey, 'The Political Economy of the Dormant Commerce Clause' (1989) 17 New York University Review of Law and Social Change 1, 18-23. Gey refers to the 'neo-classical axioms that the nation's economy can be subdivided into local and national spheres, and the corresponding policy determination that the states should be given substantial responsibility for economic regulation': at 52.

${ }^{18}$ In an early case, Chief Justice Marshall in Gibbons v Ogden (1824) 22 US 1 decided upon a broad definition of commerce, including commercial intercourse between nations, and parts of nations in all its branches; he refuted the suggestion that commerce was confined to traffic, buying or selling or the interchange of commodities. Cf cases giving Congress narrower power over commerce, such as decisions prohibiting Congress from regulating corporate governance; Bank of Augusta v Earle (1839) 38 US 519; and Cooley v Board of Wardens (1851) 53 US 299.

${ }^{19}$ Above n 16, 11.

${ }^{20}$ Ibid 23. The Business Council of Australia in its 2008 Report concludes that nothing has yet come of past COAG commitments to reform trade measurement, but notes a re-commitment by COAG in December 2007, in the form of a working party, to consider issues such as trade 


\section{SOLUTION? THE INTERPRETATION OF SECTION 92 OF THE COMMONWEALTH CONSTITUTION}

Though we might hope that the above problems could be resolved through COAG, it will be suggested that another way in which the above challenge can be resolved is through section 92 of the Commonwealth Constitution. Section 92 of the Commonwealth Constitution is one of the most litigated sections, providing a guarantee that 'trade, commerce and intercourse among the States shall be absolutely free'. It is one of the key provisions of the Constitution, reflecting one of the key reasons for the creation of Australia the concern to encourage free trade between the colonies under a common external tariff. Much debate has concerned the question of identifying precisely what it is from which trade, commerce and intercourse are to be free. There have been many challenges to state business regulations based on the section, and, to a more limited extent, to Commonwealth regulations. Perhaps the most famous use of the section was to thwart the Federal Government's plans for a nationalised banking system in Australia. ${ }^{21}$ The section was radically re-interpreted in the 1988 Cole $v$ Whitfield ${ }^{22}$ decision to prohibit (only) laws that discriminated against interstate trade and commerce for protectionist purposes. ${ }^{23}$

Recently, the section was used by the High Court of Australia to strike down state legislation seeking to regulate an Internet betting regime operating from Tasmania. The case reflects the first challenge to attempts by states to regulate Internet commerce. It may herald the start of other such challenges, and it is submitted that the case might have broader implications for the states in terms of business regulation. I will explain the case and what it decided, before considering some of the possible implications of the decision.

and professional recognition: 27. Problems with the lack of harmonisation of the trade and professional licensing were also noted by the Business Council in its report Reshaping Australia's Federation: A New Contract for Federal-State Relations (2006) and Business Council of Australia Intergovernmental Relations in Federal Systems (2006).

${ }^{21}$ Bank of New South Wales $v$ Commonwealth (1948) 76 CLR 1.

22 (1988) 165 CLR 360. See, for discussion, Dennis Rose, 'Cole v Whitfield: ‘Absolutely’ Free Trade?' in HP Lee and George Winterton (eds), Australian Constitutional Landmarks (2003) 335.

${ }^{23}$ Amelia Simpson 'Grounding the High Court's Modern Section 92 Jurisprudence: The Case for Improper Purpose as the Touchstone’ (2005) 33 Federal Law Review 445. I will refer to literature critiquing the Cole test later in this article. 


\section{A The Decision - Betfair Pty Limited v Western Australia}

Betfair held a licence under Tasmanian law to operate a 'betting exchange'. Betfair uploaded onto its computer server information about each sporting event in Australia on which bets could be placed. Registered customers of Betfair could call or e-mail through bets to its Hobart headquarters. This kind of betting differed from more orthodox betting, in that in effect customers were betting with one another rather than through a centralised body such as a TAB (often government-connected), or with a bookmaker. Customers could bet on particular events happening or not happening. Some of Betfair's customers were in Western Australia, and some of the events upon which Betfair took bets occurred in Western Australia.

The Western Australian Parliament passed the Betting and Racing Legislation Amendment Act 2006 (WA), which inserted sections 24(1aa) and 27D(1) into the Betting Control Act 1954 (WA). Section 24(1aa) made it an offence for a person to bet through a betting exchange. Section 27D(1) of the Act made it an offence to publish or otherwise make available a Western Australian race field in the course of business, unless prior approval had been obtained. Betfair had not obtained the required approval. Betfair successfully challenged the amendments, arguing that they breached the section 92 free trade and commerce protection enshrined in the Constitution. ${ }^{24}$

The result was unanimous. ${ }^{25}$

The High Court dismissed the arguments for Western Australia that appeared to assume that states had to retain an area over which they could pass business laws, even where laws regarding the Internet were concerned:

To focus upon the geographic dimension given by State boundaries, when considering competition in a market in internet commerce, presents practical and conceptual difficulties. Yet, Western Australia and supporting State interveners emphasised that s 92 permanently mandates that each State

\footnotetext{
${ }^{24}$ (2008) 234 CLR 418 ('Betfair'). See for discussion Eli Ball, 'Section 92 and the Regulation of E-Commerce: A Casenote on Betfair Pty Ltd $v$ Western Australia' (2008) 36 Federal Law Review 265; Amelia Simpson 'Betfair Pty Ltd v Western Australia' (2008) 19 Public Law Review 191.

${ }^{25}$ Joint reasons were given by Gleeson CJ, Gummow, Kirby, Hayne, Crennan and Kiefel JJ, with Heydon $\mathrm{J}$ delivering a judgment with the same effect.
} 
retain its own 'economic centre'. That proposition, as will appear from what is said later in these reasons, is overbroad. ${ }^{26}$

The joint reasons, in considering comments made by the Court in its 1990 section 92 decision in Castlemaine Tooheys $v$ South Australia, ${ }^{27}$ note that the earlier reasons

[a]ppear to discount the significance of movement of persons across Australia, and of instantaneous commercial communication, and to look back to a time of physically distinct communities located within colonial borders and separated by the tyranny of distance. ${ }^{28}$

The joint reasons in Betfair appeared to widen the immunity provided by section 92. The reasons referred to comments in Castlemaine that account would be taken of the 'fundamental consideration' that a state legislature had power to enact legislation for the well-being of its people. ${ }^{29}$ The joint reasons in Betfair concluded that such a consideration would not support much modern state regulatory legislation in the 'new economy'. ${ }^{30}$

In considering developments since its 1988 decision on section 92, the High Court highlighted the National Competition Policy, formulated under the auspices of the Council of Australian Governments (COAG), including the guiding principle that legislation should not restrict competition unless it can be shown 1) that the benefits of the restrictions to the community as a whole outweigh the costs, and 2) that the objectives of the legislation could only be achieved by restricting competition. ${ }^{31}$

In the Court's extensive use of economic literature in Betfair, it noted that one of the reasons for Australia federating was to facilitate trade among the

${ }^{26}$ Betfair (2008) 234 CLR 418, 452; the joint reasons referred to the new economy, in which internet-dependent businesses like the one considered here operate readily and deal with customers without regard to geographic boundaries.

${ }^{27}$ (1990) 169 CLR 436 ('Castlemaine Tooheys').

${ }^{28}$ Betfair (2008) 234 CLR 418, 453.

${ }^{29}$ Ibid 473 (Mason CJ, Brennan, Deane, Dawson and Toohey JJ).

${ }^{30}$ Ibid 474. As expressed by the Business Council of Australia, 'as the world globalises, barriers to the free movement of people, goods and services within Australia become increasingly anachronistic': Business Council of Australia, Reshaping Australia's Federation: A New Contract for Federal-State Relations (2006) 1. See also Geoffrey Sawer: 'if the result is eventually to leave the concept of "intrastate trade" almost empty, as it now is in the United States, this is merely the inevitable consequence of national economic integration': Australian Federalism in the Courts (1967) 206; and Gey: 'In the modern world, every commercial activity is part of interstate commerce': 'The Political Economy of the Dormant Commerce Clause’: (1989) 17 New York University Review of Law and Social Change 1, 76.

${ }^{31}$ Betfair (2008) 234 CLR 418, 452. 
colonies, and that political economists of the era had concluded that free commercial intercourse was one of the most distinctive marks of national unity. $^{32}$ The Court concluded that

[t]he creation and fostering of national markets would further the plan of the Constitution for the creation of a new federal nation and would be expressive of national unity. ${ }^{33}$

Sometimes state governments could be susceptible to local pressures to make decisions adverse to those outside the state. ${ }^{34}$

The joint reasons accepted that some regulation of interstate trade and commerce was necessary, and state laws operating in this field could be validated if they satisfied a criterion of 'reasonable necessity', which might be slightly more difficult to satisfy than previously expressed limits. ${ }^{35}$ Their Honours admitted that the claimed objective of the Western Australian government in passing the law, supposedly to 'preserve the integrity of betting', might have some justification. However, the total ban on betting exchanges and the prohibition on publishing lists was not proportionate or appropriate and adapted to the propounded legislative object. ${ }^{36}$

\footnotetext{
${ }^{32}$ Ibid 455, citing Sir Robert Palgrave, Dictionary of Political Economy (2 ${ }^{\text {nd }}$ ed, 1896) 45-6.

${ }^{33}$ Ibid 452.

${ }^{34}$ Ibid 460; they cited here Professor Tribe: '[t]hat recognition reflects not a cynical view of the failings of statesmanship at a sub-federal level, but only an understanding that the proper structural role of state lawmakers is to protect and promote the interests of their own constituents. That role is one that they will inevitably try to fulfil even at the expense of citizens of other states ... [i]n this context, the rhetoric of judicial deference to the democratically fashioned judgments of legislatures is often inapposite. The checks on which we rely to curb the abuse of legislative power - election and recall - are simply unavailable to those who have no effective voice or vote in the jurisdiction which harms them. This problem is most acute when a state enacts commercial laws that regulate extraterritorial trade, so that unrepresented outsiders are affected even if they do not cross the state's borders': American Constitutional Law ( $3^{\text {rd }}$ ed, 2000) 1051-2.

${ }^{35}$ In Cole $v$ Whitfield, the court would have allowed 'genuine' state laws regulating commerce (403), where the law had a 'real object' of prescribing standards, (1988) 165 CLR 360, 408. In Castlemaine Tooheys, the court used the concept of 'acceptable explanation or justification', (1990) 169 CLR 436, 477, in Barley Marketing Board (NSW) v Norman, the question was whether the burden on interstate trade was 'incidental' to the attainment of a non-protectionist object and not disproportionate, (1990) 171 CLR 182, 199.

${ }^{36}$ Betfair (2008) 234 CLR 418, 479.
} 


\section{B Free Movement of Labour and the Right to Trade Have Been Recognised Internationally}

The High Court of Australia has recently shown itself to be increasingly willing to consider international developments in areas to which it turns its attention. ${ }^{37}$ Forces of globalisation have created an increased recognition that our legal challenges have, more often than not, been faced by other countries. While the laws of a country are an expression of the sovereignty of its people, it makes sense in dealing with legal challenges to at least consider how these challenges have been dealt with elsewhere. The High Court in its Betfair decision referred to relevant American material, and it is submitted that the Australian law in this area could benefit from consideration of both European and American literature concerning the right of individuals to move around within a federation, and to provide services across jurisdictional boundaries, without undue restriction.

In the European Union, the free movement of persons from one Member State to another is recognised as one of the four fundamental freedoms of Union law. It is derived from article 39 (freedom of movement for workers), article 43 (freedom of establishment), and article 49 (freedom to provide services). ${ }^{38}$ Directives have been issued and cases decided in relation to general recognition of both professional education ${ }^{39}$ and vocational education. ${ }^{40}$ They are to the effect that these qualifications must be recognised in all Member States, and another Member State is not entitled to deny practice rights to a person qualified in a Member State on the basis of inadequate qualifications. ${ }^{41}$

\footnotetext{
${ }^{37}$ For example, Roach v Electoral Commissioner (2007) 233 CLR 162.

${ }^{38}$ So, for example, the requirement that an employer wishing to acquire an employee from another Member State pay a fee was held to be offensive to article 39: Union Royale Belge des Sociétés de Football Association v Bosman (C-415/93) [1995] ECR I-4921. Individuals have a right to take up and pursue activities as self-employed persons and to set up businesses under the same conditions as those laid down for its own nationals by the law of the country where such establishment is effected. There has been a move by the European Court of Justice to extend these rights of movement beyond merely economic rights, to include social and family rights: Trojani v Centre Public d'Aide Sociale de Bruxelles (C-456/02) (2004) ECR 7573; Collins v Secretary of State for Work and Pensions (C-138/02) (2004) ECR I-2703.

${ }^{39}$ Council Directive 89/48 and 2001/19/EC [2001] OJ L 206; Council Directive 2004/38/EC, [2004] OJ (L158) 77; European Commission, Reform of the System for the Recognition of Professional Qualifications (2005); European Commission, The European Qualifications Framework: A New Way to Understand Qualifications Across Europe (2006); Reyners v Belgian State (C-2/74) (1974) ECR 631.

${ }^{40}$ Directive 92/51/EEC [1992] OJ L 209 and Directive 2001/19/EC [2001] OJ L 206; Hocsman v Ministre de l'Emploi (C-238/98) [2000] ECR I-6623.

${ }^{41}$ Horatia Muir Watt, 'European Integration, Legal Diversity and the Conflict of Laws' (2005) 9 Edinburgh Law Review 6, 26. Watt says that if one Member State failed to recognise qualifications obtained in another state, it would destroy the competitive advantage conferred by the home state's potentially different legislation.
} 
State restrictions on the entitlement of a non-resident to practise in the state have been strictly limited. ${ }^{42}$ A European lawyer cannot be required to take more than one bar exam. ${ }^{43}$ Each Member State must recognise a company registered in another Member State, and cannot impose extra requirements on that company before allowing it to trade. ${ }^{44}$

It has been recognised that the object of these provisions is to encourage the optimal allocation of resources within the Union and to maximise wealth creation. $^{45}$

The experience in the United States is similar, and the High Court of Australia referred to the American equivalent provisions in its Betfair decision. Clearly there are historical parallels in terms of the movement to federation and the concern to reduce commercial wars between states. ${ }^{46}$ The right to freedom of interstate trade and commerce, and to movement around the federation, is

${ }^{42}$ The European Court of Justice found in Gebhard v Consiglio dell'Ordine degli Avvocati e Procuratori di Milano (Case C-55/94) [1995] ECR I-4165, that national measures liable to hinder or make less attractive the exercise of fundamental freedoms guaranteed by the Treaty (including the right to freedom of movement) were only valid if they (a) were applied in a non-discriminatory manner (b) were justified by imperative requirements in the public interest (c) must be suitable to attain the objective they pursue, and (d) they must not go beyond what is necessary to attain it. A regulation requiring members of the Paris Bar to have only one office, and for it to be in France, was struck out by the European Court of Justice in Klopp v Ordre des Avocats au Barreau de Paris (Case 107/83) (1984) ECR 2971. See for further discussion Paul Craig and Grainne De Burga, EU Law: Text, Cases and Materials ( $3^{\text {rd }}$ ed, 2003) 772-85; Francesca Strumia, 'Citizenship and Free Movement: European and American Features of a Judicial Formula for Increased Comity' (2006) 12 Columbia Journal of European Law 713, and Gonzalo Villalta Puig, 'Free Movement of Goods: The European Experience in the Australian Context' (2001) 75(10) Australian Law Journal 639, and Gonzalo Villalta Puig, 'A European Saving Test for Section 92 of the Australian Constitution' (2008) 13(1) Deakin Law Review 99.

${ }^{43}$ Francesca Strumia, 'Citizenship and Free Movement: European and American Features of a Judicial Formula for Increased Comity’ (2006) 12 Columbia Journal of European Law 713, 749.

${ }^{44}$ Kamer van Koophandel en Fabrieken voor Amsterdam v Inspire Art Ltd (C-167/01) [2003] ECR I-10155.

${ }^{45}$ Paul Craig and Grainne de Burca, EU Law: Text, Cases and Materials ( ${ }^{\text {rd }}$ ed, 2003) 581. To like effect see Chandra Shah and Michael Long, 'Labour Mobility and the Mutual Recognition of Skills and Qualifications: European Union and Australia/New Zealand' (Working Paper No 65, Centre for the Economics of Education and Training, Monash University, 2000) 4: 'The European Commission considers capacity for occupational mobility to be essential if the EU economy was to be efficient and competitive in the global market and if skills imbalances across sectors and regions were to be alleviated. The critical factor in building this capacity requires the development of the human capital potential of the union's citizens together with the processes for its recognition and transferability across borders'.

${ }^{46}$ Cole $v$ Whitfield (1988) 165 CLR 360, 387, referring to intercolonial free trade as a 'lion in the path' of federation; H P Hood and Sons Inc v Du Mond (1949) 336 US 525, 533-4. 
recognised in at least three places within the US Constitution. ${ }^{47}$ These provisions can be read together as reflecting a desire to protect and promote the cohesiveness of the federal union. ${ }^{48}$ The obvious equivalents to these provisions in the Australian Constitution are sections $92^{49}$ and $117 .^{50}$

A recent US Supreme Court decision referred to a citizen's 'right to travel' being protected by the privileges and immunities clause. ${ }^{51}$ Article 4 of the United States Constitution has been used to successfully attack state legislation imposing residency requirements or providing lesser benefits or higher fees for non-residents. ${ }^{52}$ Under the dormant commerce clause, states' requirements that sellers of particular products, such as liquor, should possess a state-issued licence have been struck down, even if the licence is potentially

\footnotetext{
${ }^{47}$ Article 1, section 8 allows Congress to pass laws regulating interstate trade, and article 4, section 2 and the Fourteenth Amendment provide that the citizens of each state shall be entitled to the privileges and immunities of citizens of the United States.

48 Jide Nzelibe, 'Free Movement: A Federalist Interpretation' (1999) 49 American University Law Review 433, 445; Brannon Denning, 'Why the Privileges and Immunities Clause of Article IV Cannot Replace the Dormant Commerce Clause Doctrine' (2003) 88 Minnesota Law Review 384.

${ }^{49}$ Murphy J expressly referred to the American authorities in terms of the constitutional right to travel in Miller v TCN Channel Nine Pty Ltd (1986) 161 CLR 556, 582 (he then compared these authorities with s 92 jurisprudence in Australia).

${ }^{50}$ Embodying the right to freedom from discrimination on the basis of residence. Mason CJ, in the landmark s 117 case of Street $v$ Qld Bar Association (1989) 168 CLR 461, 491, referred with approval to art 4 and the Fourteenth Amendment of the United States. Section 117 was inspired by the American provisions: George Winterton et al, Australian Federal Constitutional Law: Commentary and Materials ( $2^{\text {nd }}$ ed, 2007) 661; Clifford Pannam, 'Discrimination on the Basis of State Residence in Australia and the United States' (1967) 6 Melbourne University Law Review 105. I do not dwell in detail in this article on the requirements of s 117, but there is a high degree of overlap between that section and section 92, given that they both embrace a prohibition on discrimination against a thing or person that has the characteristic of interstatedness.

${ }^{51}$ Saenz $v$ Roe (1999) 526 US 489. The right was infringed by a Californian law restricting the welfare benefits available to a newly arrived resident compared with a long-term resident. See also Shapiro v Thompson (1969) 394 US 618; United States v Guest (1966) 383 US 745; and Edwards v California (1941) 314 US 160; cf Wilson Pasley, 'The Revival of 'Privileges and Immunities' and the Controversy Over State Bar Admission Requirements: The Makings of a Future Constitutional Dilemma' (2002) 11 William and Mary Bill of Rights Journal 1239.

52 Supreme Court of New Hampshire v Piper (1985) 470 US 274 (inhouse residency requirements for bar membership invalid) (with obvious similarities to the Australian case of Street v Queensland Bar Association (1989) 168 CLR 461; United Building and Construction Trades Council v Mayor of Camden (1984) 465 US 208 (residency requirement for employment on state-funded projects invalid); Austin v New Hampshire (1975) 420 US 656 (state imposition of higher tax rate for non-residents invalid); Saenz v Roe (1999) 526 US 489 (lower benefits to newly arrived residents of California compared with benefits to long-term residents invalid); and Toomer $v$ Witsell (1984) 334 US 385 (higher commercial shrimp licence fees for nonresidents invalid); cf Gillian Metzger, 'Congress, Article IV and Interstate Relations' (2007) 120(6) Harvard Law Review 1468.
} 
obtainable by the out-of-state business, because of the inferred protectionist purpose of the legislation. ${ }^{53}$ A state requirement that an out-of-state liquor seller have some physical presence in the state in order to sell online to customers there has been recently struck down as contrary to the dormant commerce clause, on the basis of discrimination against interstate traders. ${ }^{54}$ The Supreme Court considered that the scheme raised the costs for out-ofstate producers which would likely be passed on to customers and make their products less financially viable. Arguments by the states that they were trying to discourage purchase of alcohol online by minors (and that the legislation was therefore legitimate regulation) were not accepted. ${ }^{55}$

Legislation can be attacked by use of the dormant commerce clause either because it discriminates against interstate trade and commerce, or because it unreasonably burdens interstate commerce. ${ }^{56}$ Links have been acknowledged with competition law here. ${ }^{57}$

Considering a Rhode Island statute which defined debt collecting as legal practice and then limited such collecting to licensed Rhode Island lawyers, the First Circuit found the law unconstitutional under the dormant commerce clause:

By defining all debt collection as the practice of law, and limiting this practice to members of the Rhode Island bar, Rhode Island effectively bars out-of-staters from offering a commercial service within its borders and confers the right to provide that service - and to reap the associated

${ }^{53}$ Heald v Engler 342 F 3d 517 (6 th $^{\text {th }}$ Cir, 2003), cert denied; Dickerson v Bailey 336 F 3d 388 ( $5^{\text {th }}$ Cir, 2003); and Beskind $v$ Easley 325 F 3d 506 ( $4^{\text {th }}$ Cir, 2003). The possible applicability of the Twenty-First Amendment is outside the scope of this article.

${ }^{54}$ Note that discrimination was found although it could have been argued that the requirements of presence within the state applied equally to interstate and local traders.

55 Granholm v Heald (2005) 544 US 460 (Kennedy, Scalia, Souter, Ginsburg and Breyer JJ; Rehnquist CJ, Stevens, O’Connor and Thomas JJ dissenting). The court also referred to the fact that the legislation would likely have the effect of reducing competition.

56 Oregon Waste Systems Inc v Department of Environmental Quality (1994) 511 US 93; Maine v Taylor (1986) 477 US 131; Pike v Bruce Church Inc (1970) 397 US 137; Granholm v Heald (2005) 544 US 460; Donald Regan, 'The Supreme Court and State Protectionism: Making Sense of the Dormant Commerce Clause' (1986) 84(6) Michigan Law Review 1091. Arguments that the state legislation is justified on public policy grounds will be considered but are often unsuccessful: David Day, "The "Mature" Rehnquist Court and the Dormant Commerce Clause Doctrine: The Expanded Discrimination Tier’ (2007) 52 South Dakota Law Review 1.

57 Justice Cardozo found that the commerce clause forbade a state law burdening interstate trade and commerce 'when the avowed purpose of the [law] as well as its necessary tendency is to suppress or mitigate the consequences of competition between the States': Baldwin $v$ GAF Seelig Inc (1935) 294 US 511, 522. 
economic benefit - upon a class largely composed of Rhode Island citizens. ${ }^{58}$

The right of a citizen to live and work where he/she wishes, to earn a living by any lawful means, and to pursue any vocation, has also been recognised by the Supreme Court as protected by the Constitution. ${ }^{59}$ An ordinance requiring an employer of any person moving into the area, or changing jobs in the area, to obtain identifying particulars such as fingerprints from their new employee have been struck out. ${ }^{60}$ The Court has found that people may come within the definition of commerce. ${ }^{61}$

\section{Some Australian Precedents}

There have been some past examples where the High Court and Privy Council have considered state business licensing schemes in the context of section 92 . These cases pre-date the 1988 watershed decision in Cole $v$ Whitfield, ${ }^{62}$ and for this reason their continuing correctness must be firmly questioned. However, some of the issues with which earlier cases grappled remain current post-Cole. For example, it has always been accepted, and continues to be accepted, that the section cannot be read and applied literally to proscribe any laws that impact on interstate trade and commerce. It has been the case, and continues to be the case, that at least some state regulation is acceptable. The question is always where the line should be drawn. The examples below

\footnotetext{
${ }^{58}$ National Revenue Corp v Violet 807 F 2d 285 (1 $1^{\text {st }}$ Cir, 1986) [14]. As Charles Wolfram puts it 'the states [today] are by and large quite restrictive about admitting out-of-state lawyers ... The reasons given for the restrictions are probably largely pious eyewash. The real motivation, one strongly suspects, has to do with cutting down on the economic threat posed for in-state lawyers ... by competition with out-of-state lawyers': 'Sneaking Around in the Legal Profession: Interjurisdictional Unauthorized Practice by Transactional Lawyers' (1995) 36 South Texas Law Review 665, 679; Gerard Clark, 'The Two Faces of Multijurisdictional Practice' (2002) 29 North Kentucky Law Review 251; Andrew Perlman, 'A Bar Against Competition: The Unconstitutionality of Admission Rules for Out of State Lawyers' (2004) 18 Georgetown Journal of Legal Ethics 135; cf Dent v State of West Virginia (1889) 129 US 114, where the Supreme Court upheld the right of a state to require proof of evidence of a certain level of skill and knowledge in order for a person to be allowed to practise a profession. The dominant view in the United States mirrors the High Court of Australia's rejection of residency requirements as a basis for practising law within an Australian jurisdiction under s 117: Street v Queensland Bar Association (1989) 168 CLR 461.

${ }^{59}$ In the context of the Fourteenth Amendment see: Allgeyer v Louisiana (1897) 165 US 578 (Justice Peckham) and John Harrison, 'Reconstructing the Privileges and Immunities Clause' (1992) 101 Yale Law Journal 1385.

${ }^{60}$ Service Machine and Shipbuilding Corp v Edwards 617 F 2d 70 ( $5^{\text {th }}$ Cir $)$, affirmed $101 \mathrm{~S} \mathrm{Ct}$ 310 (1980).

${ }^{61}$ Ibid.

62 (1988) 165 CLR 360.
} 
suggest where the line has been drawn in contexts relevant to the focus of this article.

Perhaps the leading example was Hughes and Vale Pty Ltd v State of New South Wales, ${ }^{63}$ concerning New South Wales transport regulations which prohibited a person from operating a public motor vehicle without a licence. A public motor vehicle was defined as one that was used in the course of any trade or business. The Act provided for the licensing authority to have regard to various factors in assessing an application. A unanimous Privy Council struck down the Act as being offensive to section 92. In doing so, the Privy Council discussed building by-laws which provided that compliance with them gave the lodger an as-of-right approval to commence work. Such an approach would be valid, according to the Privy Council, but

[s]uch a law differs vitally from a prohibition subject to obtaining a licence which may be granted or withheld at discretion. The only reason why such a system would not be regarded as satisfactory in such legislation as that now under consideration is that such legislation is not really concerned - or at any rate is by no means solely concerned - with the safety of public transport. It is concerned very largely with restricting the development, in competition with existing railways, of modern and convenient methods of transport, and one of its supposed advantages is that the discretion to withhold licences can be used to protect the trade of one State at the expense of another. It is, for example, obviously within the sphere of practical politics that it should be thought in Melbourne that Cootamundra ought to drink Victorian beer and not South Australian beer. The protection of the industries of one State against those of another State was, of course, one of the primary things which s 92 was designed to prevent, but, if the legislation now in question is valid, effect can easily be given to such an opinion without anybody knowing anything about it. ${ }^{64}$

\footnotetext{
63 (1954) 93 CLR 1.
}

${ }^{64}$ Ibid 27-8. The author is wary of relying on comments in a section 92 case decided prior to Cole, which changed the landscape. However it is submitted that these comments are relevant post Cole in as far as they refer to the purpose of the legislation. The High Court in Cole required that, in order that section 92 apply, the law be passed for a protectionist purpose, and the quotation above is similar in considering the reason for the passage of legislation to be relevant to its constitutionality under section 92 - whether it be to preserve public safety or to deter competition. The quotation also refers to the understandable tendency for a regional government to seek to preserve its local industry, a sentiment reiterated in the Betfair decision: 'legislators in one political subdivision may be susceptible to pressures which encourage decisions adverse to the commercial and other interests of those who are not their constituents and not their taxpayers': (2008) 234 CLR 418, 459. 
In North Eastern Dairy Co Limited v Dairy Authority of New South Wales, ${ }^{65}$ a Victorian milk producer sold milk to customers in New South Wales, contrary to New South Wales provisions requiring that any milk sold in the State be pasteurised by the holder of a New South Wales licence. This milk had not been so pasteurised. A majority of the Court found the legislation to be invalid due to section 92. Barwick CJ found that the legislation was attempting to allow New South Wales producers to monopolise the supply of milk. ${ }^{66}$ Although it was laudable to seek to provide wholesome milk, as was arguably the purpose of this legislation, this was not the only practical way to achieve that purpose. ${ }^{67}$ It was not established that milk pasteurised in accordance with Victorian law was less wholesome than that of New South Wales. ${ }^{68}$ The regulations directly produced the result that a trader could not lawfully sell within the State a commodity of commerce, except on terms dictated by the State. $^{69}$

Mason $\mathrm{J}$ referred to a test of discrimination that would later find support by the unanimous court in Cole:

The legislature has selected a mode of regulation which ... is calculated to burden, indeed to destroy, the interstate trade in pasteurised milk, in preference to other modes of regulation which would involve no discrimination against the Victorian product. As the defendant has failed to show that the discriminatory mode of regulation selected is necessary for the protection of public health, it is in my judgment not a reasonable regulation of the interstate trade in pasteurised milk. ${ }^{70}$

It can be noted here that Mason $\mathrm{J}$ found the state regulation discriminatory against interstate trade, although the requirement that milk be pasteurised by a licence holder applied regardless of the source from which the milk came.

65 (1975) 134 CLR 559. See similarly Dean Milk Co v Madison (1951) 340 US 349, where the United States Supreme Court struck out an ordinance prohibiting the sale of milk if it was not pasteurised within a five mile radius of the town square.

${ }^{66}$ To like effect, Mason J stated: 'the legislation ... is calculated to burden, indeed to destroy, the interstate trade in pasteurised milk, in preference to other modes of regulation which would involve no discrimination against the Victorian product': North Eastern Dairy Co Limited v Dairy Authority of New South Wales (1975) 134 CLR 559, 608.

${ }^{67}$ Ibid 578. Mason $\mathrm{J}$ also noted that alternative means of obtaining a similar result were available - making it an offence to sell pasteurized milk which had not been pasteurised to the prescribed standard: at 608 .

${ }^{68}$ Ibid 601 (Gibbs J).

${ }^{69}$ Ibid 589 (Barwick CJ).

${ }^{70}$ Ibid 608. The joint reasons in Betfair referred with approval to this extract from the judgment of Mason J in North Eastern Dairy: Betfair (2008) 234 CLR 418, 477. Again, the language used - specifically concepts of 'discrimination' - arguably means that the decision remains good law today notwithstanding the new approach heralded in Cole. 
In Boyd $v$ Carah Coaches Proprietary Limited, ${ }^{71}$ New South Wales regulations prohibited an individual or firm from carrying on business as a travel agent unless they held a licence. The regulations established a Travel Agents Registration Board, empowering it to issue licences at its discretion. Several criteria were noted as the basis for the exercise of the Board's discretion, including whether or not the applicant was a fit and proper person to hold such a licence, and the adequacy of the applicant's educational attainments or experience. Again, a majority of the High Court struck out the regulations as offensive to section 92 .

Gibbs J, for example, found that a statutory provision forbidding a person from carrying on an ordinary trade without a licence, and giving the licensing authority an uncontrolled discretion to refuse to grant a licence, could not be applied to interstate trade due to section $92 .{ }^{72}$ He objected to the 'fit and proper' criterion as involving an overly wide discretion. ${ }^{73}$ Similarly, Mason J objected to the power of the Board to refuse a licence on arbitrary and unspecified grounds which could be obnoxious to the concept of free trade guaranteed by section $92 .^{74}$

Though most of the past cases have concerned the trade and commerce aspect of section 92, I should note that the section also protects 'intercourse' among the states. The High Court in Cole suggested a broader view of the protection to be given to the intercourse aspect of the section

A constitutional guarantee of freedom of interstate intercourse, if it is to have substantial content, extends to a guarantee of personal freedom 'to pass to and fro among the State without burden, hindrance or restriction. ${ }^{, 75}$

Subsequent High Court decisions on the intercourse aspect of section 92 have focused on whether the purpose of the law is to burden interstate intercourse,

\footnotetext{
${ }^{71}$ (1979) 145 CLR 78. Similar issues arose and a similar result ensued in Perre v Pollitt (1975) 135 CLR 139.

${ }^{72}$ Boyd v Carah Coaches Proprietary Limited (1979) 145 CLR 78, 84.

${ }^{73}$ Ibid 85.

${ }^{74}$ Ibid 97.

${ }^{75}$ Cole v Whitfield (1988) 165 CLR 360, 393 (citations omitted). It seemed at that stage that the right to freedom of intercourse was to be considered quite separately and distinctly from the right to freedom of trade and commerce: at 388. The right is similar to the privileges and immunities doctrine in the United States, which, as has been discussed above, has been interpreted to guarantee freedom of movement.
} 
and whether the impediment to such intercourse is greater than is reasonably necessary in order to secure a legitimate object. ${ }^{76}$

There are several precedent examples, then, where the High Court has struck out business licensing schemes on the basis that their requirements are offensive to the economic unity that was envisaged by the founding fathers in constructing the section 92 freedom. While the test for invalidity of a provision under section 92 has changed, these cases can still be used to support an argument as to the invalidity of state licensing schemes, given that there are comments in the cases couched in the language of discrimination and protectionism.

\section{FUTURE WORK FOR SECTION 92 TO Do}

Members of the High Court in the recent Betfair case have shown that they are willing to recognise the requirements and realities of the 'new economy' in interpreting section 92 of the Constitution. Business groups have been saying consistently that the economic realities of the $21^{\text {st }}$ century in Australia today require that we move away from a state-based occupational licence regime, in order to free up labour to move to where it is most needed, and to where it can more efficiently be utilised. Again, this is not an issue that is unique to Australia. Other federations such as the United States and the European Union have recognised the right of a worker to move freely within the federation for work purposes, and to have their qualifications and skills recognised in the new state. This right is not absolute, but restrictions on such a freedom must be clearly justified. This is for sound economic reasons. Although we in Australia are always wary about applying solutions developed in other countries without adaptation to reflect local requirements, and although our constitutional provisions are expressed in different terms from foreign laws, it is submitted that, like the other jurisdictions discussed here, Australia needs to protect the right of free movement within the federation. The High Court clearly has the ability to do so through its interpretation of section 92 of the Australian Constitution.

It is submitted that state-based licensing regimes remain vulnerable to challenge under section 92 of the Constitution, as currently interpreted, just as they have been challenged in the past.

${ }^{76}$ APLA Ltd $v$ Legal Services Commissioner (NSW) (2005) 219 ALR 403; Cunliffe v Commonwealth (1994) 182 CLR 272. See also James Stellios, 'The Intercourse Limb of Section 92 and the High Court's Decision in APLA Ltd v Legal Services Commissioner (NSW)(2006) 17 Public Law Review 10. 


\section{A Example ${ }^{77}$}

Assume that Rob is a licensed electrician in Western Australia, and wishes to work as an electrician in Queensland. If Queensland regulations required him to undergo further training to be able to work as an electrician in that state, or did not recognise his experience in Western Australia as fulfilling any work experience requirements for registration in Queensland, the Queensland regulations might be challengeable on (at least) two bases: ${ }^{78}$

(a) that they interfere with freedom of intercourse among the States as it applies to Rob, on the basis that Rob would be moving to Queensland for work reasons, and if there are barriers to him being able to work there, he is less likely to move;

(b) if Rob intends to move to Queensland permanently, that such restrictions interfere with trade and commerce among the States, by inhibiting someone who wishes to move between States for business purposes. American authorities establish that the movement of people can constitute commerce. ${ }^{79}$

If Rob wished to remain resident in Western Australia but merely fly to Queensland to work on some projects, as many service providers do, these regulations would even more seriously inhibit interstate trade and commerce.

It is arguable that these state-based licensing schemes are at least prima facie designed to inhibit competition for work in the state imposing the requirements. The courts have been willing to go behind the claimed justification for laudable-sounding laws, to find out the real motivation for their enactment. In Hughes and North Eastern Dairy, the Court found as a fact that business licensing schemes had been passed for protectionist reasons. The High Court of Australia in Betfair and the United States Supreme Court have both referred to the need, in interpreting these kinds of provision, to allow competition if at all possible. Removing state-based restrictions on the right to practise a particular profession or trade, or at the very least requiring very strong justification for their retention, would assist in encouraging

\footnotetext{
${ }^{77}$ This discussion takes place on the assumption of the continuing applicability of the Cole discriminatory protectionism test, though later it is briefly asked what the situation would be if, as some commentators suggest, evidence of protectionism were not required to be shown in order that an Act be found to be invalid according to section 92.

${ }^{78}$ I do not dwell here on arguments surrounding section 117 of the Constitution. However, however that section was, of course, applied to state-based restrictions on the right of a New South Wales resident to practise in Queensland in Street v Qld Bar Association (1989) 168 CLR 461.

${ }^{79}$ Hughes and Vale Pty Ltd $v$ State of New South Wales (1954) 93 CLR 1.
} 
competition among labour, and among service providers. It is sensible to interpret legal rules to provide for economically desirable outcomes.

The states will probably seek to justify their regimes on non-protectionist grounds. The High Court's 'reasonable necessity' test might be used to support their arguments; in other words, that the regulations are reasonably necessary to secure a legitimate objective. However, it might be expected to be a rare case where this test was satisfied. For example, it is hard to think of a genuine reason why a person licensed as a refrigeration mechanic in New South Wales should not have an automatic right to perform the same task in Victoria. Support for this approach is evident in past High Court decisions on section 92 such as Hughes and North Eastern Dairy, which recognised the potential for state-based licensing regimes to be anti-competitive.

Some might argue that a state-based licensing regime is not discriminatory, since it applies to those who have lived locally for a long time, as well as to those who were licensed in another jurisdiction and have recently moved between states. It is true that the court has required there to be discrimination in order that an Act breach section $92 .{ }^{80}$ However, as indicated above, Mason $\mathrm{J}$ in North Eastern Dairy (who used the concept of discrimination in assessing the Act's validity under section 92) ${ }^{81}$ found that, although in that case the requirement for milk sold to be certified by a licensed pasteuriser applied regardless of the milk's origin, the Act was discriminatory, ${ }^{82}$ providing an extra burden on interstate trade.

Further, we should recall that the provisions successfully challenged in Betfair did not apparently single out interstate trade and commerce for discriminatory treatment, yet were struck down. Further, in the section 117 case of Street $v$ Queensland Bar Association, the High Court found that a residency requirement for legal practice in Queensland was discriminatory contrary to that section. The fact that the residency requirement applied to both local and interstate practitioners did not save the requirement from invalidity. ${ }^{83}$ There is no evidence that the concepts of freedom from discrimination are to be

${ }^{80}$ Cole v Whitfield (1988) 165 CLR 360, 399 (Mason CJ, Wilson, Brennan, Deane, Dawson, Toohey and Gaudron JJ); Permewan Wright Consolidated Proprietary Limited $v$ Trewhitt (1979) 145 CLR 1.

${ }^{81}$ North Eastern Dairy Co Limited v Dairy Authority of New South Wales (1975) 134 CLR 559, 608.

${ }^{82}$ The Privy Council in Hughes and Vale Pty Ltd $v$ State of New South Wales (1954) 93 CLR 1, 22 also declared that 'their Lordships have rejected the theory that because a law applies alike to inter-state commerce and to the domestic commerce of a state, it may escape objection notwithstanding that it prohibits restricts or burdens interstate commerce'.

83 (1989) 168 CLR 461. 
applied differently in the context of sections 92 and 117 and so the two sections are not considered here as giving rise to separate arguments.

In the same way, regulations which state that a person who has obtained a particular qualification or trade or the right to practise in a field in one Australian jurisdiction must undergo further training or qualifications in another jurisdiction before practising there are also seen to be discriminatory. They require the person to jump through two hoops - the requirements of the jurisdiction whence they have come, and of the jurisdiction in which they are now seeking registration. The 'two hoop' or 'double burden' concept was recognised recently in the context of the European Union:

The posting of a worker could not require the employer to comply with a second set of territorially applicable rules ... in addition to those already complied with in the home country (unless there was a general interest justification for doing so). In all these cases, the double burden test works without difficulty; mutual recognition serves to protect a competitive advantage acquired under the rules applicable in the home state. ${ }^{84}$

Analogously (given the above quotation), in the section 92 case of Bath $v$ Alston Holdings Pty Ltd, ${ }^{85}$ a majority of the High Court invalidated a taxation provision that had the effect of removing a competitive advantage that lowercost interstate goods had.

As indicated above, on the current interpretations given to 'discrimination' in sections 92 and 117, a requirement which overturns a competitive advantage will be found to be discriminatory. We would then consider whether the discrimination was justified, using the High Court's 'reasonable necessity' test from Betfair. The state pleading justification would have to make its case, citing the interests, presumably, of public safety or health. It would be hard to make this case when another state, the state of the person's origin, had presumably made the assessment on similar grounds when giving the person the right to conduct the practice or business. Very strong evidence would need to be led by the state whose laws were under challenge, and the prima facie position would be that such laws were protectionist. ${ }^{86}$ Although there is evidence that at least one founding father did not intend section 92 to apply to such licensing regimes, ${ }^{87}$ this is not considered determinative of how the

\footnotetext{
${ }^{84}$ Watt, above $\mathrm{n} 41,26$ (emphasis added).

85 (1988) 165 CLR 411, 426 (Mason CJ, Brennan, Deane and Gaudron JJ; Wilson, Dawson and Toohey JJ dissenting).

${ }^{86}$ Again, the High Court was prepared to conclude that licensing-based schemes were in fact protectionist in nature in Hughes and Vale and North Eastern Dairy.

${ }^{87}$ For example, Sir Samuel Griffith, commenting on the intended meaning of the section, claimed 'it is clearly not proposed to interfere with the internal regulation of trade by means
} 
section can be applied to a very different economy in the early years of the $21^{\text {st }}$ century. ${ }^{88}$

The High Court in section 92 has been concerned, in applying the 'reasonable necessity' test, with whether the claimed objectives of the legislation could be achieved in a manner that was less offensive to competition than the provisions of the challenged legislation. ${ }^{89}$ Given the move to national standards in particular fields, I would suggest that, if states have genuine concerns about the standards that should be required for entry to particular trades or professions, the legitimate way to express these concerns is to participate in formulating the national standards, rather than trying to go it alone with their own regulations.

\section{B Should Evidence of a 'Protectionist Purpose' Be Necessary in Applying Section 92?}

The above discussion is premised on a need to prove that state-based licensing systems were introduced at least partly for protectionist purposes. As indicated, there is precedent for such schemes being viewed in this light.

of licences' in 'Notes on the Draft Federal Constitution Framed by the Adelaide Convention of 1897’ Queensland Legislative Council Journals (1897) 47 Part I, 12.

88 Sir Anthony Mason has commented on the advent of rapid transportation and communications, and modern technology, resulting in the integration of trade within Australia: 'The Australian Constitution 1901-1988' (1988) 62 Australian Law Journal 752. See also Windeyer J in Victoria $v$ The Commonwealth (1971) 122 CLR 353, 395. The High Court recently, in New South Wales v Commonwealth (2006) 229 CLR 1, 97, referred to the idea of pursuing the intention of the founding fathers as more often than not pursuing a mirage.

89 Betfair (2008) 234 CLR 418, 452 (joint reasons), North Eastern Dairy Co Ltd v Dairy Industry Authority of New South Wales (1975) 134 CLR 559, 578 (Barwick CJ) and 608 (Mason J). This discussion takes place in the context of a broader debate about the meaning of 'proportionality' as it is applied in section 92 cases. Some distinguish between robust proportionality and abstract proportionality. Robust proportionality considers three issues: the suitability of the measure used to achieve the desired end, whether the measure is necessary in that there are no alternative practical measures available, and whether the measure is excessive or disproportionate to the ends achieved or sought to be achieved. Abstract proportionality, on the other hand, considers only the last of these criteria. See, for further discussion of this issue, Jeremy Kirk, 'Constitutional Guarantees, Characterisation and the Concept of Proportionality’ (1997) 21 Melbourne University Law Review 1, 4; Gonzalo Villalta Puig, The High Court of Australia and Section 92 of the Australian Constitution (2008) 145-54; Gonzalo Villalta Puig, 'A European Saving Test for Section 92 of the Australian Constitution’ (2008) 13(1) Deakin Law Review 99, 106-112 and Amelia Simpson, 'Grounding the High Court's Modern Section 92 Jurisprudence: The Case for Improper Purpose as the Touchstone’ (2005) 33(3) Federal Law Review 445. 
However, it is worth pointing out that other writers have questioned whether there should be a need to prove a protectionist purpose in order that a law be found to have breached section 92. They argue that the section was included in the Constitution in order to create a common market. The argument is that, consistently with this purpose, laws which discriminate against interstate trade and commerce should be prima facie struck out as offensive to section 92, whether or not a purpose of protectionism can be shown. As one of the leading advocates of this reform measure argues:

The narrowness of the scope [of the existing test] excludes many laws and measures from the jurisdiction of s 92 even though their purpose and effect may be to restrict the common market ... ${ }^{90}$

These authors believe that section 92 was included in the Constitution with the intention that it would provide for a common market. This view is inconsistent with the view of history taken by the High Court in Cole, but enjoys some support among other commentators, ${ }^{91}$ as well as being reflected in views of judges ${ }^{92}$ in some section 92 cases. A leading commentator on section 92 jurisprudence acknowledges that the current discriminatory protectionism test has its limitations:

[T] he Court assumes a narrower and more workable role as the enforcer of one aspect of the achievement of economic unity in a federal system, the prevention of state protectionism resulting from the imposition of discriminatory burdens on interstate trade. If this be thought to be too narrow, it should be remembered that other kinds of laws or practices that detract from the achievement of an internal common market or otherwise threaten national economic unity (usually state laws or actions ...) may require different remedies, such as overriding national legislation or uniform agreement among the states. ${ }^{93}$

${ }^{90}$ Gonzalo Villalta Puig, The High Court of Australia and Section 92 of the Australian Constitution (2008) 121; Gonzalo Villalta Puig 'A European Saving Test for Section 92 of the Australian Constitution’ (2008) 13(1) Deakin Law Review 99.

${ }^{91}$ For example, Dennis Rose 'Federal Principles for the Interpretation of Section 92 of the Constitution' (1972) 46 Australian Law Journal 371, 374: 'The discrimination might be intended to serve protective purposes ... but even if it is not actually intended to serve such purposes, it can nevertheless be reasonably held to infringe the "free trade" purpose of s 92'; Peter Lane, The Australian Federal System (1979) 763: 'truth to tell, if one takes s 92 at face value ... one could not really restrict its injunction to ... protectionist burdens only'.

${ }^{92}$ For example, Mason J in Finemore's Transport Pty Ltd $v$ New South Wales (1978) 139 CLR 338, 352.

${ }^{93}$ Michael Coper, 'Freedom of Interstate Trade and Commerce' in Tony Blackshield, Michael Coper and George Williams (eds), The Oxford Companion to the High Court of Australia (2002) 354, 356. 
It is not proposed to dwell here on this discussion, since it is not the main focus of this article, but certainly it would be easier to challenge state-based licensing systems on the basis of section 92 if it were not necessary to show a purpose of protectionism. Mutual recognition among states of a business or occupational licence might be more consistent with the common market of which those above spoke in framing their views on the interpretation, and true purpose of, section 92.

\section{CONCLUSION}

The recent High Court of Australia decision in Betfair has raised hopes that state-based licensing regimes could be challenged on the basis of the section 92 freedom. A broad interpretation of the freedom of movement around Australia for work purposes, and a consequent narrow interpretation of the obstacles in the path of workers who wish to exercise that right, would be consistent with the approach taken in two other leading federations of the world. It is justified on economic efficiency grounds since it allows capital and labour to be put to more efficient uses. It might also better reflect the vision of the founding fathers that section 92 would serve to create a common market in Australia.

Business groups have sought greater integration of Australia's labour force, and have pointed to state-based licensing regimes as creating barriers and inhibiting business potential. While the law should not necessarily always be applied in a way that businesses want, all Australians benefit when companies based in Australia can operate more efficiently. Thus, state licensing schemes that do not recognise (truly) equivalent qualifications or experience gained elsewhere in Australia are discriminatory on the 'two-hoops' thesis. A state can argue for such a regime, but should be required to present very strong evidence as to how the laws meet the 'reasonable necessity' test. The law can thus be interpreted in a way that meets sound economic goals for the Australian federal system early in its second century. 